\title{
ON COVID-19 DIFFUSION IN ITALY: DATA ANALYSIS AND POSSIBLE OUTCOME
}

\author{
Nicola Fabiano ${ }^{a}$, Stojan N. Radenovićb \\ a Ton Duc Thang University, Faculty of Mathematics and Statistics, \\ Ho Chi Minh City, Vietnam; \\ Ton Duc Thang University, Nonlinear Analysis Research Group, \\ Ho Chi Minh City, Vietnam, \\ e-mail: nicola.fabiano@tdtu.edu.vn, corresponding author, \\ ORCID iD: Dhttps://orcid.org/0000-0003-1645-2071 \\ ${ }^{\mathrm{b}}$ University of Belgrade, Faculty of Mechanical Engineering, \\ Belgrade, Republic of Serbia, \\ e-mail: radens@beotel.net, \\ ORCID iD: Dhttps://orcid.org/0000-0001-8254-6688
}

DOI: 10.5937/vojtehg68-25948; https://doi.org/10.5937/vojtehg68-25948

FIELD: Mathematics

ARTICLE TYPE: Original scientific paper

ARTICLE LANGUAGE: English

\begin{abstract}
:
Introduction/purpose: At the end of 2019, the Coronavirus disease 2019 (COVID-19) was identified first in the Hubei province of China and then it spread over the world causing the coronavirus pandemic. The virus has given very different outcomes in different countries up to day - at the time of writing, Italy has a record number of deaths caused by coronavirus (Google, 2020).

Methods: A mathematical model is applied to describe the behavior of number of cases with respect to time, the obtained data is compared and some predictions given.

Results: The model chosen to represent the evolution of the spread of the disease allows making some projections for the future.

Conclusions: Sound projections could be created with accurate numbers provided the current situation is not perturbed by other external influences.
\end{abstract}

Key words: Coronavirus, COVID-19, differential equation, data fit.

\section{Introduction}

The aim of the paper is to describe in somewhat rigorous terms the spreading of the disease in time, i.e. the number of positive cases for Covid-19. This is a classical problem of population growth that applies equally well to the rate of reproduction of an animal species or of a virus. 
Qualitatively, one should expect for a population number to grow exponentially in the first phase and then, with the increase of competition and diminishing resources, to slow down until reaching a plateau in time, i.e. a static situation.

By means of the model applied and available data, it is possible to determine when the growth of cases should diminish, when it will stop and what the total number of cases will be.

\section{Growth equation}

The equation used to describe the growth of the number of cases is the same used in the description of the growth of generic population in time $x(t)$, sometimes called the logistic equation (Verhulst, 1838):

$$
\frac{d x(t)}{d t}=\frac{x(t)}{a}\left(1-\frac{x(t)}{c}\right)
$$

where $a$ is related to the growth rapidity and $c$ is the asymptotic total number of cases, or population.

The solution of the equation should be written as

$$
x(t)=\frac{c}{1+\exp ((b-t) / a)}
$$

where the parameter $b$ is related to the initial condition

$$
x(0)=\frac{c}{1+\exp (b / a)}
$$

and also $b$ is the growth invertion point, i.e.

$$
\frac{d^{(2)} x(b)}{d t^{(2)}}=0
$$

for $t=b, d x(t) / d t$ reaches the maximum.

In order to determine the three positive parameters $a, b$ and $c$, one has to compare it to the existing situation.

There exists a GitHub account with Italian official data for the coronavirus disease (Ministero della Salute, 2020) which is updated on a 
daily basis and covers most information available since the 24th of February, 2020.

The paper will focus on the date column $A$ and the total number of cases, $\mathrm{K}$ of the csv file and will fit the three parameters $a, b$ and $c$ of solution (2) to the data.

According to the data presented on the 28th of March 2020, 34 days after the start of the disease data collection, the three parameter fit gives the following results:

Table 1 - Fit for parameters $a, b$ and $c$

Таблица 1 - Ввод по параметрам $a, b$ и с

Табела 1 - Уклапање за параметре $a, b$ и с

\begin{tabular}{|l|l|l|l|}
\hline Parameter & Value & Error & Error \% \\
\hline$a$ & 5.32546 & $+/-0.07999$ & $1.502 \%$ \\
\hline$b$ & 28.721 & $+/-0.2253$ & $0.7846 \%$ \\
\hline$c$ & 125043 & $+/-2349$ & $1.878 \%$ \\
\hline
\end{tabular}

It can be clearly seen that the numerical results of this fit are very precise, and the associated error is contained within less than $2 \%$ (the plot is subsequently going to show they are very accurate as well).

As previously discussed, $b$ and $c$ are the most relevant parameters, the $b$ value of about 29 days shows that the inversion point has already been reached and the growth of new cases is slowing down. The $c$ value of around 125 thousand represents the total number of cases, which is still rather far from the current number of total cases (around 100 thousand).

Plot 1 shows the fit of curve (2) with respect to the collected data.

One can clearly see that the agreement with the points is excellent. In fact, only 3 parameters are enough for a fit with a time span exceeding one month. The superposition of the two curves shows that the agreement is also very accurate. 


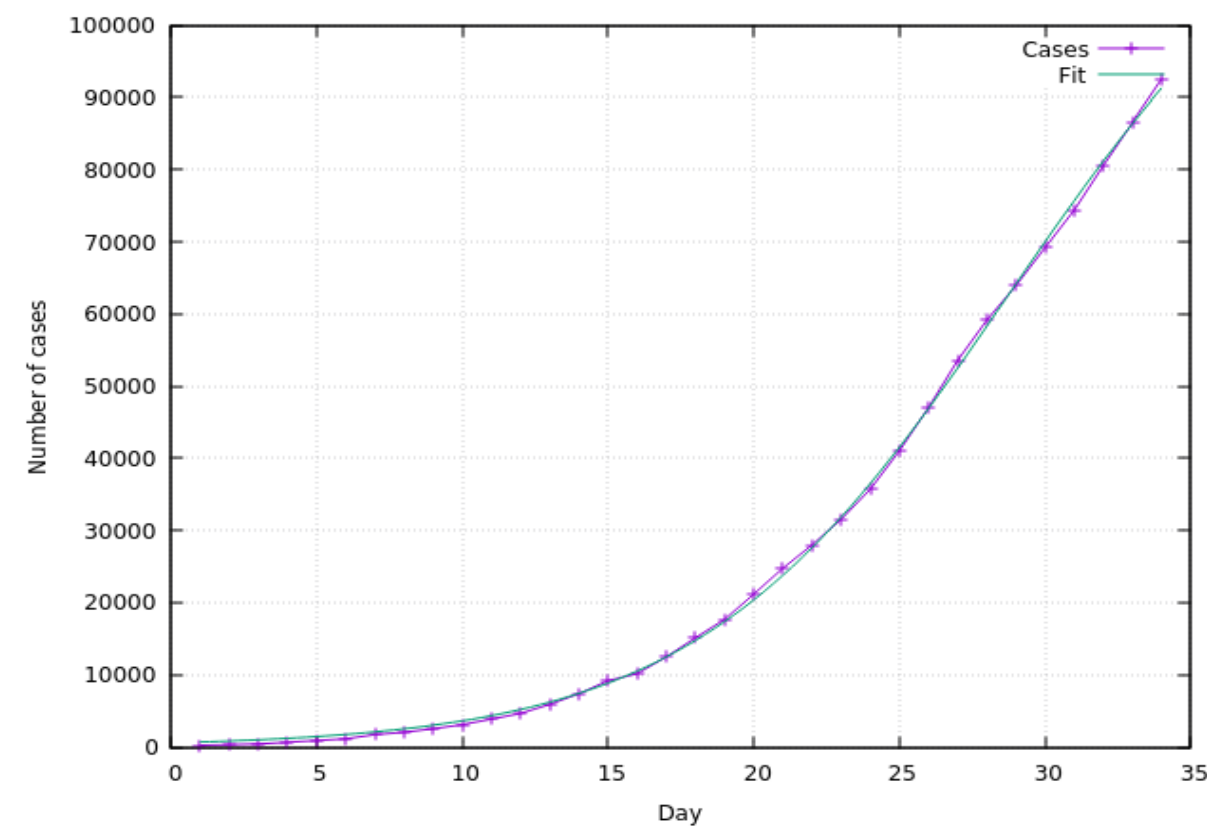

Figure 1-Data fit: the number of cases with respect to the number of days Puc. 1 - Совпадение данных: число случаев в соотношении с числом дней Слика 1 - Уклапање података: број случајева у односу на број дана

\section{Tentative prediction for the future}

Using the results obtained in the previous section, we will try to predict the future behavior of the number of cases, using the values obtained by the fit.

We will also compare the data to the derivative of equation (2) (multiplied by a factor of 10 in order to enhance it) in order to better identify the inversion point.

Figure 2 shows the plot of the obtained data so far as a function of time, together with equation (2) for 10 days in the future and its derivative, augmented by a factor of 10 so that it is visible on the plot (the authors are actually concerned only with its maximum value).

A similarity of this derivative to the Gaussian distribution is also worth noticing as well as the number of cases that resembles the error function. The latter shows, however, a fundamental difference from equation (1) that governs the real case, i.e. the tails that would assume that the beginning of the covid disease started in the distant past.

As it can be seen, the graph representing the number of cases slows down its growth and soon approaches a quasi static regime. This 
behavior is also confirmed by the derivative function which shows how its peak value has already been surpassed. According to Table 1, the end of the disease should be reached when the number of cases approaches 125 thousand units.

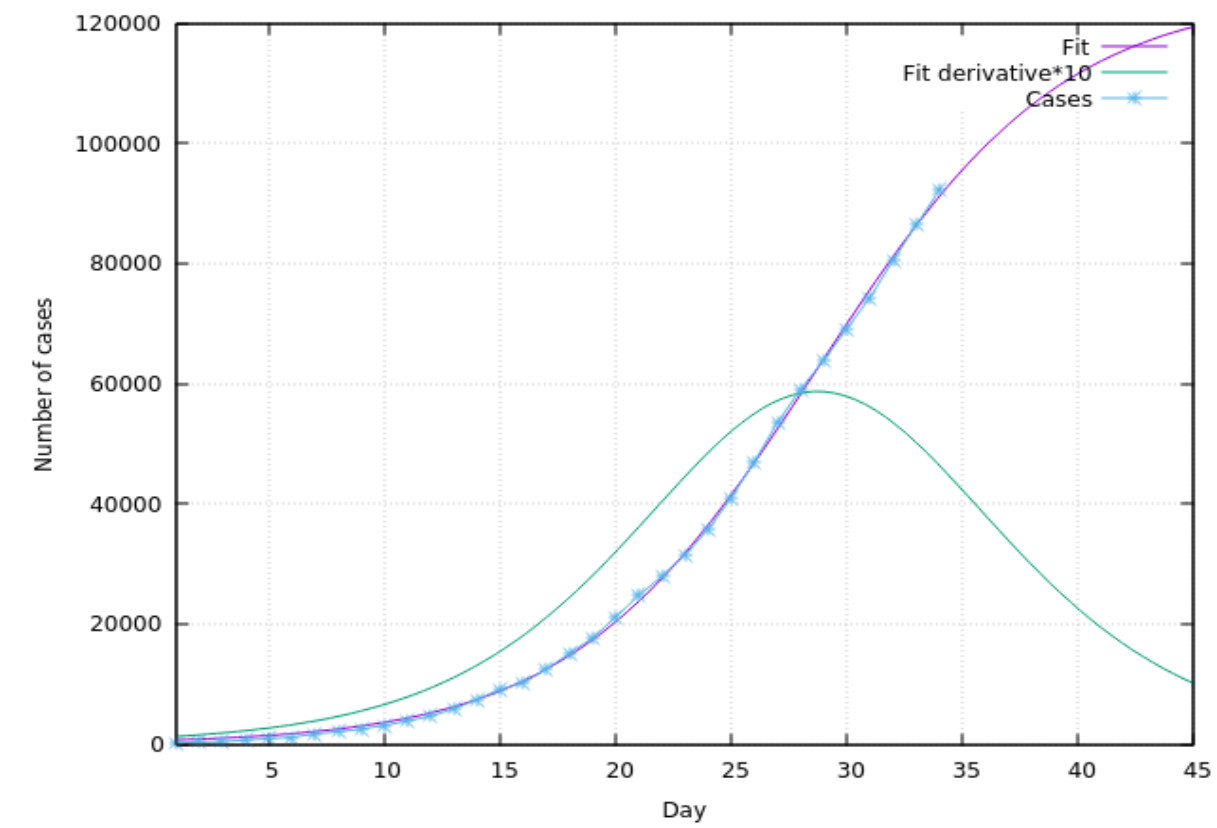

Figure 2 - Extrapolation of the number of cases for the next future Puc. 2 - Экстраполяция числа случаев на ближайшее будущее Слика 2 - Екстраполација броја случајева у блиској будућности

Of paramount interest is, of course, a reasonable estimate of the end of the disease. Bearing in mind that the steady state value $c$ of equation (2) is asymptotic, and that the number itself carries an implicit error of its true value depending on the measurement used (various kinds of swabs, CT scans, etc) and by solving the equation in time $t$ for the parameters found in Table 1:

$$
x(t)=\text { Fraction of } c
$$

one obtains the values shown in Table 2: 
Table 2 - Estimated time $t$ for the end of the disease spread based on the value $c=125043$ obtained in Table 1

Таблица 2 - Расчетное время $t$ завершения распространения заболевания на основании значения с = 125043, полученного из таблицы 1

Табела 2 - Процењено време $t$ краја ширења заразе, засновано на вредности с = 125 043, добијеној из табеле 1

\begin{tabular}{|l|l|}
\hline Fraction of $c$ & Time $t$ \\
\hline $99.9 \%$ & 65.5 Days \\
\hline $99.99 \%$ & 77.8 Days \\
\hline $99.999 \%$ & 90.0 Days \\
\hline
\end{tabular}

In other words, it means that, in order to reach a total number of cases equal to $99.9 \%$ of $c$ as in the first line, one should wait to the end of April 2020 approximately. The other two values will be reached around the middle and the end of May 2020, respectively.

Our prediction model made some implicit assumptions; namely, that the system is closed, so there are neither external interactions over the whole time, nor congregating of people that could drastically increase the local number of patients even in an isolated system, and that we are actually dealing with only one kind of a virus strain, which has already been discussed in (Cereda et al, 2020) and which may explain the extreme agressiveness of the Italian situation compared to those in other countries (see (Google 2020) for data on other countries).

In reality, there is a possibility that interactions among different countries will restart before the situation in the whole world settles down, meaning that some minor disease spreads could reoccur before its disappearing, looking like damp copies of the derivative of equation (2) repeated in a more or less periodic way depending on the reopening of borders for goods deliveries and traveling.

\section{Conclusion}

The model of population growth has been used and it has been found out that it agrees with the current data of Covid-19 diffusion surprisingly well, using just a few parameters. The determination of these parameters allows us to notice that the peak growth that happened at about 30 days after the start of the disease has already been surpassed. The total number of Covid-19 cases, about 125 thousand, is still far off and should be reached in approximately 30 days, provided Italy remains isolated from other countries and keeps away from internal traveling as much as possible to avoid other possible causes of infections. 


\section{References}

Cereda, D. et al. 2020. The early phase of the COVID-19 outbreak in Lombardy, Italy [online]. Available at: https://arxiv.org/abs/2003.09320 [Accessed: 31 March 2020].

-Google. 2020. COVID-19 Information \& Resources [online]. Available at: https://www.google.com/covid19/ [Accessed: 31 March 2020].

-Ministero della Salute. 2020. Data of COVID-19 disease situation in Italy 2020 [online]. Available at: https://raw.githubusercontent.com/pcm-dpc/COVID19/master/dati-andamento-nazionale/dpc-covid19-ita-andamento-nazionale.csv (in Italian) [Accessed: 31 March 2020].

Verhulst, PF. 1838. Notice sur la loi que la population suit dans son accroissement. Correspondance mathématique et physique, 10, pp.113-121 (in French).

О РАСПРОСТРАНЕНИИ ЗАБОЛЕВАНИЯ СОVID-19 В ИТАЛИИ: АНАЛИЗ ДАННЫХ И ВОЗМОЖНЫЙ ИСХОД

Никола Фабиано ${ }^{\text {a }}$ корреспондент, Стоян Н. Раденович ${ }^{6}$

а Университет Тон Дук Тханг, Факультет математической статистики, Хо Ши Мин, Вьетнам;

Университет Тон Дук Тханг, Исследовательский отдел нелинейного анализа, Хо Ши Мин, Вьетнам

${ }^{\sigma}$ Белградский университет, Машиностроительный фракультет,

г. Белград, Республика Сербия

РУБРИКА ГРНТИ: 27.29.00 Обыкновенные дифференциальные уравнения

ВИД СТАТЬИ: оригинальная научная статья

ЯЗЫК СТАТЬИ: английский

Резюме:

Введение/цель: В конце 2019 года Коронавирусная инфекция (COVID-19) первоначально была обнаружена в китайской провинции Хубэй, а затем распространилась по всему миру, вызвав пандемию коронавируса. Вирус проявлялся в разных странах по-разному, на сегодняшний день, пока мы пишем данную статью, в Италии зарегистрировано рекордное количество умерших от коронавируса (Google, 2020).

Методы: Вышеописанная прикладная математическая модель, фиксирует поведенческие особенности случаев в отношении времени, выполнено сравнение с полученными данными и приведен прогноз на будущее. 
Результаты: Данная модель представляет эволюцию расширения заболевания, и дает возможность создать соответствующие условия в будущем.

Выводы: Звуковые проекции могут дать точные числа, но только при условии, если текущая ситуация не будет нарушена другими внешними воздействиями.

Ключевые слова: Коронавирус, COVID-19, диффференциальное уравнение, совпадение данных.

О ДИФУЗИЈИ COVID-19 У ИТАЛИЈИ: АНАЛИЗА ПОДАТАКА И МОГУЋИ ИСХОД

Никола Фабиано ${ }^{\text {, аутор за преписку, Стојан Н. Раденовић }}{ }^{б}$

а Универзитет Тон Дук Танг, Факултет математике и статистике,

Хо Ши Мин, Вијетнам;

Универзитет Тон Дук Танг, Истраживачка група за нелинеарну анализу,

Хо Ши Мин, Вијетнам

${ }^{\sigma}$ Универзитет у Београду, Машински фракултет,

Београд, Република Србија

ОБЛАСТ: математика

ВРСТА ЧЛАНКА: оригинални научни рад

ЈЕЗИК ЧЛАНКА: енглескИ

Сажетак:

Увод/циљ: Крајем 2019. године, инфекција коронавирусом (COVID19) идентифрикована је најпре у кинеској провинцији Хубеи, а затим се проширила по свету узрокујући пандемију. Различит је број заражених овим вирусом у земљама широм света. У тренутку писања овог текста у Италији је забележен највећи број смртних исхода проузрокованих коронавирусом (Google, 2020).

Mетоде: Примењен је математички модел који описује карактеристике броја случајева у односу на време. Извршено је поређење са добијеним подацима и прогнозиран даљи ток оболевања од инфекиије коронавирусом.

Резултати: Овај модел, који представља еволуцију ширења болести, омогућава да се изврше одређена предвиђања ширења коронавируса у будућности.

Закључци: Поуздано се могу предвидети тачне бројке броја умрлих и инсрицираних под условом да се на тренутну ситуацију не одразе други спољни утицаји.

Кључне речи: коронавирус, COVID-19, диференцијална једначина, уклапање података. 
Paper received on / Дата получения работы / Датум пријема чланка: 01.04.2020. Manuscript corrections submitted on / Дата получения исправленной версии работы / Датум достављања исправки рукописа: 06.04.2020.

Paper accepted for publishing on / Дата окончательного согласования работы / Датум коначног прихватања чланка за објављивање: 08.04.2020.

(c) 2020 The Authors. Published by Vojnotehnički glasnik / Military Technical Courier

(www.vtg.mod.gov.rs, втг.мо.упр.срб). This article is an open access article distributed under the terms and conditions of the Creative Commons Attribution license (http://creativecommons.org/licenses/by/3.0/rs/).

() 2020 Авторы. Опубликовано в «Военно-технический вестник / Vojnotehnički glasnik / Military Technical Courier» (www.vtg.mod.gov.rs, втг.мо.упр.срб). Данная статья в открытом доступе и распространяется в соответствии с лицензией «Creative Commons» (http://creativecommons.org/licenses/by/3.0/rs/).

( 2020 Аутори. Објавио Војнотехнички гласник / Vojnotehnički glasnik / Military Technical Courier (www.vtg.mod.gov.rs, втг.мо.упр.срб). Ово је чланак отвореног приступа и дистрибуира се у складу са Creative Commons licencom (http://creativecommons.org/licenses/by/3.0/rs/).

(c) (i) 